\title{
Changes since the turn of the century in the fish fauna and the fisheries of the Oslofjord
}

\author{
JoHAN T. RuUD \\ Institute of Marine Biology, University of Oslo, Oslo, Norway
}

KURZFASSUNG: Veränderungen der Fischfauna und der Fischerei des Oslofjords seit der Jahrhundertwende. Das Material zu dieser Untersuchung stammt aus zwei Quellen; (a) vier Untersuchungen über die Fischfauna des Oslofjords im Zeitraum zwischen 1897 und 1967, und (b) Statistiken für den Zeitraum von 1872 bis 1964 über die Fischmengen, die im inneren Oslofjord gefangen und an die Fischhalle in Oslo geliefert worden sind. Ein Vergleich der Resultate mit den vier Untersuchungen über die Fischfauna zeigt, daß vier Arten von Tiefwasserfischen aus dem inneren Oslof jord völlig verschwunden sind, nämlich Etmopterus spinax, Somniosus microcephalus, Artediellus uncinatus und Icelus bicornis, die beiden zuletzt genannten wahrscheinlich schon vor 1930. Eine Anzahl anderer Arten, die früher häufig waren, sind jetzt selten. Statistische Erhebungen über die im Oslofjord gefangenen Fische lassen erkennen, daß die Erträge seit den zwanziger und dreißiger Jahren stark zurückgegangen sind. Gleichzeitig hat die Zahl der Fischer abgenommen. Es wird die Schlußfolgerung gezogen, daß die Veränderungen des Oslofjords sich besonders in den letzten 30 Jahren für mehrere Fischarten als schädigend erwiesen haben. Diese Auffassung wird unterstützt durch die Untersuchungen von Dannevig (1945) und Oppenheimer (1955), die gezeigt haben, daß die reiche Bakterienflora des Oslofjords für die Entwicklung der pelagischen Fischeier schädlich ist.

\section{IN'TRODUCTION}

It is probably a general and widespread experience - everywhere where fishing is going on - that professional and sports-fishermen from time to time will complain that the fish stocks are failing and their fishery is ruined. The explanations they give are almost as a rule coloured by personal experience and interest, and the scapegoats blamed cover a long register.

From 1932 I was for several years acting secretary to a society for the promotion of fisheries in the inner Oslofjord, and I can give evidence that the Oslofjord fishermen make no exception from this habitual conduct. In the last 20 or 30 years, however, their attention has with growing concern been concentrated on the assumed or visible consequences of the pollution of the fjord by sewage.

As mentioned in my introductory article, we were in the early thirties aware of the fertilizing effect of pollution. The landed quantities of fish caught in the fjord were for some species still good, some years extremely good. But one damage following the free discharge of sewage into the fjord had long been visible, namely an increasing 
eutrophication of the inner estuaries and bays in the neighbourhood of the city, a development gradually destroying grounds previously fit for profitable fishing.

Naturally, therefore, the studies of the biology of the fjord, taken up in the early thirties, were to some extent focused on the fish fauna and the fisheries.

\section{MATERIAL}

We have two sources from which we can draw material for a comparison to illustrate the development which has taken place in the fish fauna, namely results of various studies of the fish fauna itself, and the statistics available for a long series of years of catches of fish taken in the fjord and landed at the fish market.

The pertinent studies of the fish fauna in the Oslofjord are: One by HJORT \& DAHL (1900) where a list is given of various species of fish found in deep waters, one by HJORT \& RUUD (1938) in which the species of fish caught in 24 experimental hauls with a prawn trawl are listed, an unpublished graduation thesis by STAALESEN on the studies of fish caught in prawn trawls in 1962 to 1963 and finally a comprehensive study by Lid (1967) who examined the fish caught in about 1000 prawn trawl catches in the years 1963 to 1967.

The statistics available has been collected by "The Society for the Promotion of the Fishery of the Oslofjord inside Drøbak" for the years 1872 to 1955, for later years by "The Professional Fishermens Organization". The statistics concern only the fish landed for sale at the Oslo fish market, and although it may well reflect the chief variations that have taken place in the available fish stocks, we know nothing whatsoever of the quantities sold locally or used in the fishermens own households, and we can only guess what has been taken by sports-fishermen. We may expect that these quantities are fairly constant, or that they vary with a certain and regular trend, and that the great fluctuations seen in the statistcis, therefore, reflect similar fluctuations in the total catches taken.

\section{CHANGES OBSERVED IN THE COMPOSITION OF THE FISH FAUNA OF THE OSLOFJORD}

Comparing the results of the 4 investigations mentioned above we observe that four species of fish known as fairly common in deep water of the Oslofjord in 1897 were not found in 1962-63 or the comprehensive examinations in 1963 to 1967. They are: The Greenland shark-Somniosus microcephalus (BLoch \& ScHNEIDER), the black spiny dogfish Etmopterus spinax (L.), and 2 arctic bullheads, Artediellus uncinatus (REINH.), and Icelus bicornis (ReInH.).

In the first decade of this century the fishermen were well aware of a stock of Greenland shark living in the deep waters of the Bunnefjord. Because they were known to damage deep fishing gear, a bonus was paid for every shark killed, and the last bonus was paid in 1916. Since then no Greenland shark has been reported seen or taken in the inner Oslofjord. The 2 arctic bullheads had most certainly also disap- 
peared before 1933; they were never found in the catches examined by HJORT \& RuUD.

Etmopterus spinax was found in small numbers in 1933-34 and must have disappeared later. It is very unlikely that it should have escaped observation in the many catches examined in 1963-67.

These four species are described as arctic or deep-water species and they have been fished in deep boreal waters as far south as in the Gullmarfjord on the Swedish west coast. Now they have disappeard from the Oslofjord, probably for ever. One might contend that the Greenland shark has been exterminated by intensive fishing, but this explanation does not hold good for the 2 bullheads and for Etmopterus.

An interesting coincidence should also be recorded: Halibut, Hippoglossus bippoglossus (L.) belonging to the same deep water community as the Greenland shark and others, were formerly quite often landed from the inner Oslofjord. The last report of landing is from 1920. Evidently it has disappeared about the same time as the Greenland shark. We must assume that the species mentioned here all did exist in the Oslofjord near to their limits of tolerance and that slight changes in temperature or oxygen content can be decisive for their survival within the fjord. A new immigration from deeper waters outside the Drøbak still seems very unlikely.

A number of other species formerly fairly common in deep waters in the inner fjord, and still common outside are now reported as rare inside Drøbak, such as Raja radiata Donovan, Chimera monstrosa, L., Gadiculus thori, Schmid, Lumpenus lampretaeformis, WALBAum, Lycodes vabli gracilis, M. SARs, Lycenchelys sarsii,(COLLETT), Anarrbicas lupus, L., Sebastes viviparus, KRöYER and others. Apart from the species mentioned above, the species-composition of the fish fauna in the inner Oslofjord does not seem to have changed.

\section{FLUCTUATIONS IN THE QUANTITIES OF FISH LANDED FROM THE OSLOFJORD}

The total quantities of fish and other marine products landed at the fish market from the inner Oslofjord show great fluctuations from year to year and over periods of years.

We had a series of years from 1916 to 1923 with extremely good landings, thus in 19162400 tons, of which 1500 tons were herring, 1270 tons in the category "small herring". As late as in 1938, a total landing of 1800 tons were reported, but of these 1500 tons were sprat, which this year gave an extremely good fishery in inner Oslofjord.

In contrast to such good years we had a series of poor years in the early 1950's. The total quantity landed in 1953 reached a minimum of 113 tons. That year the fishery for all important species failed. However, later the reported landings have reached even lower figures, e.g. in 1964 only 73 tons. The overall trend is, therefore, one of decreasing landings of fish from the inner fjord.

However, the landings consist of numerous species and since the various species are subject to great natural fluctutations, usually not correlated in time, landings of the individual species must be studied in more detail. The maximum yields mentioned above are of interest as an illustration of the fish production capacity of the fjord at 
its best. They correspond to about $125 \mathrm{~kg} /$ hectar (about $50 \mathrm{~kg} / \mathrm{acre}$ ). To this quantity should be added the unknown, but certainly not negligible quantity sold locally or taken by sportsfishermen.

It should be observed, however, that the greatest landings concern pelagic fish, such as mackerel, herring and sprat, and we do not know to what extent the stocks of these species are dependent on immigration from the outer fjord and the open Skager-Rak.

We know that mackerel, herring and sprat are spawned and hatched in the fjord and that sometimes very rich year classes grow up there. Mature mackerel immigrates for feeding and spawning in the fjord, sometimes in huge swarms, sometimes failing, and to some extent this may be the case with mature herring and sprat as well. However, in years with very great landings of mackerel and herring the reports are usually given with separate figures for large and small fish as for herring landed in 1916 and mentioned above. The fishery for sprat is chiefly a fishery for immature fish grown up in the fjord.

The cod in the inner Oslofjord has been subject to more systematic studies than any other species, and it is fairly certain that the stocks of cod are chiefly of local origin, the offspring of a spawning by a local stock in the inner fjord (RUUD 1939).

In the following discussion we will concentrate on a study of cod and of herring and mackerel in the Oslofjord.

\section{DISCUSSION}

\section{The cod}

The commercial fishing for cod in the inner Oslofjord has for years been mainly a trap-fishery. The number of traps were in 1936 estimated to about 2000 , and the weekly catches in good years can very between 1 and a good $2 \mathrm{~kg}$ per trap.

The fluctuations in the total landings from the inner fjord are shown in Figure 1 with curves for reported quantities and for the running 5-year average. A periodicity of 20 to 22 years is apparent, and the periods show increasing levels up to 1920 . The yearly average for the period 1872 to 1889 was 44 tons, for the period 1890 to 1910 , 57 tons and for 1911 to 1932,74 tons. For the period 1933 to 1955 the average fell to 16 tons.

Fluctuations of short duration in the reported quantities can easily be understood as fluctuations in the abundance of the various year classes, since the cod in the Oslofjord is recruited to the fishery at an age of $1^{1 / 2}$ years. Fluctuations of longer duration are well known in many fisheries. In the Lofoten fishery there are similar fluctuations of 20 to 25 years' duration, but they are not corresponding to the fluctuations observed in the cod fishery in the Oslofjord, which is natural, since the recruitment to the mature stocks fished in Lofoten occurs at an age of 10 years as an average.

The very good fishery in the Oslofjord in the 1920's can be understood as the result of a series of rich year classes in quick succession. It is known from neighbouring waters of the Norwegian Skager-Rak coast that the year classes of cod 1911, 1918, 
1919,1922 , and 1924 were all rich, the year classes 1925, 1928 and 1932 very rich, and most of the others were estimated as average. Only three really poor year classes were recorded in this period, namely 1913, 1926 and 1930 (SUND 1936).

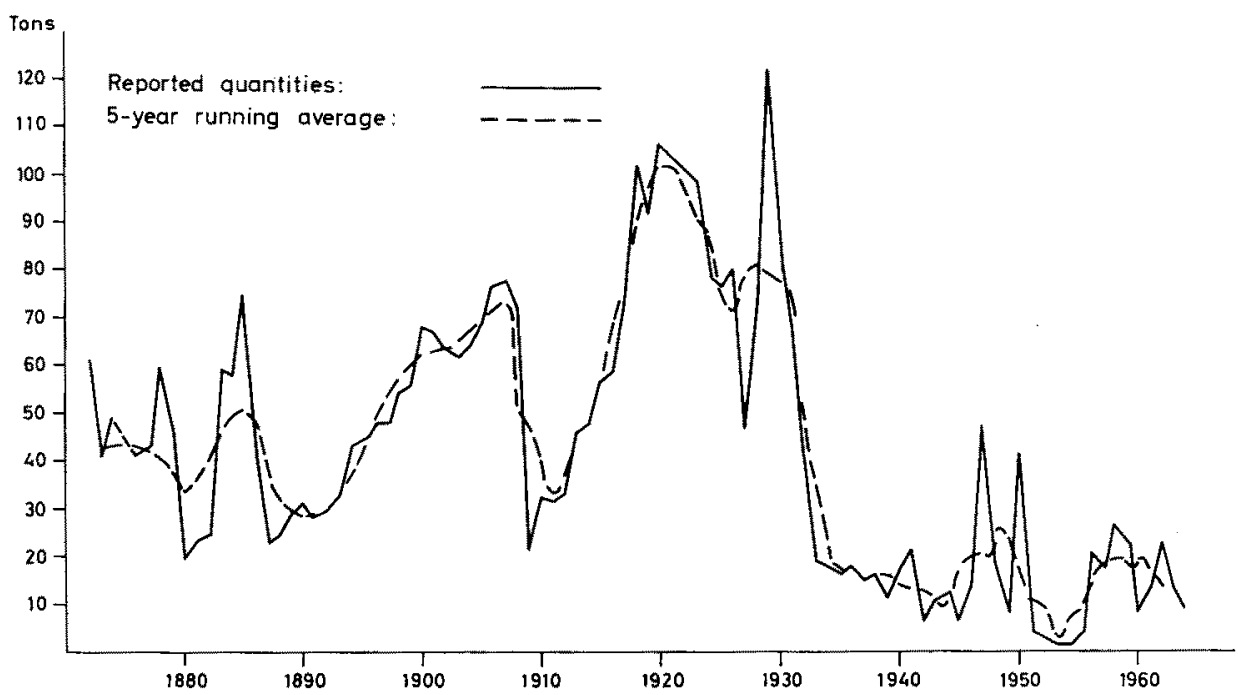

Fig. 1: Annual landings of cod from the Oslofjord inside Drøbak

There are reasons to believe that the two year classes 1925 and 1928, recorded as very rich on the Skager-Rak coast, were successful also in the inner Oslofjord, but evidently this was not the case with the third very rich year class, 1932. The landed quantities fell rapidly from 120 tons in 1929 to 20 tons in 1933, and have later never reached as much as 50 tons again. The quick decrease is surprising also because there was no known decrease in effort. The number of fishermen registered was practically the same in this period, the total numbers in 1930 and 1934 were 392 and 422 , of which 172 and 157 were classified as full time fishermen.

\section{The pelagic species herring and mackerel}

The great and rapid fluctuations in the landings of herring and mackerel from the inner fjord are shown in curves for 3-year running averages in Figure 2. For both species we had a series of very good years from 1911 to 1919 or 1920 , culminating for herring in 1916 with 1500 tons and for mackerel in 1918 with 800 tons. The average landing of herring in this period was about 700 tons, of mackerel about 400 tons per year. In the following years there is a decreasing trend with a few years of moderately good landings, such as 1928, 1936 and 1945 for herring and 1945 to 1948 for mackerel.

The very great landings of herring and mackerel occur in years when the quantities of small herring and small mackerel are abundant and contributing greatly to the catches. The abundance of small mackerel can only depend on the success of the local 
spawning, hatching and successive growth of larvae and young fish. The mature mackerel, however, is certainly, and the mature herring is probably to some extent immigrating from the outer fjord and Skager-Rak for feeding and for spawning. The

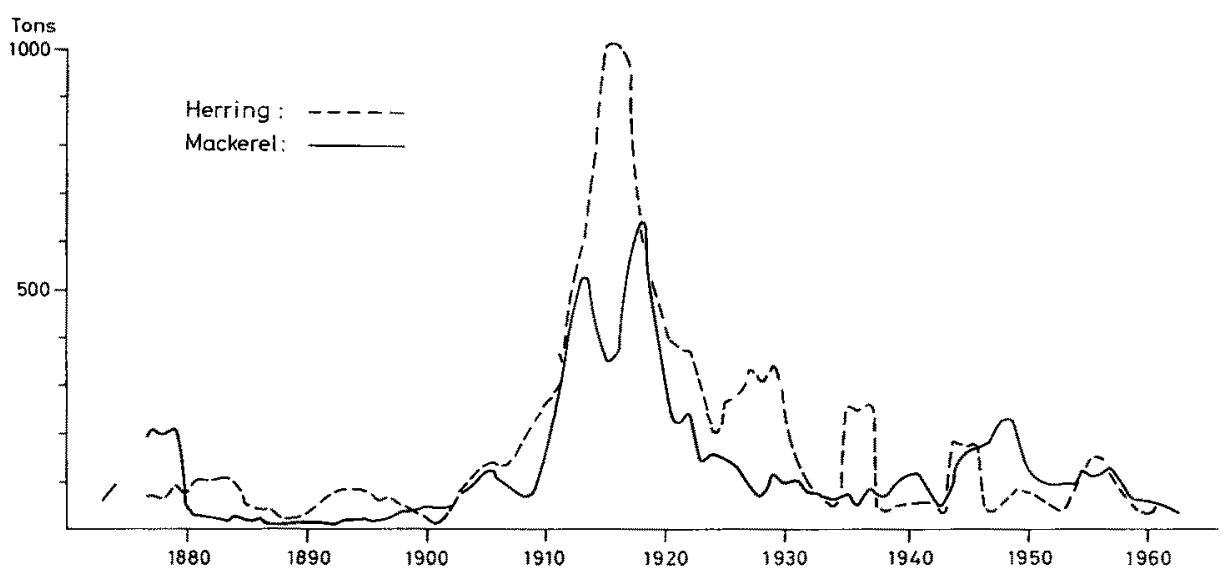

Fig. 2: Annual landings of herring and mackerel from the Oslofjord inside Drøbak.

(3-year running averages)

abundance of these categories in the inner fjord may, therefore, be dependent on the sizes of the stocks outside and such hydrographic conditions which regulate their migrations.

The decrease in the landings after 1920 has occurred at a time when no decrease in effort is apparent. On the contrary, the introduction and growing use of purse seines in the fishery for pelagic fish should have given greater catches in the years after 1920 if the stocks of fish available for fishing had been as abundant as before.

For the sake of comparison, we have studied the fluctuations in the herring fisheries in neighbouring waters, in the entrance to the Oslofjord and at the Swedish west coast (ANDERsSon 1958), and we have become convinced that the good and poor years for landings at Oslo fishmarket do not coincide with similar fluctuations in these fisheries.

\section{CONCLUSION}

The material presented above shows that significant changes have taken place in the fish fauna and in the availability of certain fish stocks to commercial fishing. Four species have disappeared completely and other species have become rare in the course of the last 30 years or so. The landings of cod, herring and mackerel, used here for a closer study, are in recent years less than $1 / 4$ of what they were 30 or 40 years ago.

Commercial- and sports-fishermen are convinced that the chief reason for this deplorable development is to be sought in the increasing pollution by sewage from the city of Oslo and the neighbouring settlements. Some of them are old enough to 
remember that some small rivers running out in the harbour of Oslo had runs of spawning sea trout and salmon 50 or 60 years ago, and nobody can doubt that these runs have been spoiled by sewage and industrial waste.

As mentioned before, we saw as late as in the early thirties chiefly the beneficial effects of the fertilization by sewage, but some warnings that a secondary pollution, due to over-fertilization were in progress could be clearly seen. Other articles will discuss some of these consequences, here we will draw attention to some investigations by DANnEvig (1954), who in regular surveys of eggs and young fish in the inner Oslofjord, in the years 1936 to 1940, observed that the mortality of fish eggs apparently were much higher in the inner fjord than outside. Many eggs could be found after a profuse spawning, but all in early stages of development only, and hatching was evidently not successful, since the search for young fish in the littoral zone in the autumn gave only negligible results. DANNEvig suggested that the surface of the eggs was overgrown by bacteria and other organisms to an extent lethal to the egg, and this was later corroborated by some more specific bacteriological studies by OpPENHEIMER (1955).

The decrease in fish stocks in the inner Oslofjords may for some species to some extent be due to overfishing, but there is good evidence that the waters of the inner Oslofjord are now unfavourable or even injurious to the hatching of fish eggs and the development and growth of fish larvae.

\section{SUMMARY}

1. The material for this study is drawn from two sources, (a) investigations of the fish fauna in the inner Oslofjord between 1897 and 1967, (b) fish landing statistics available since 1872 at the Oslo fish market.

2. The investigations of the fish fauna reveal that 4 species of fish -2 sharks and 2 arctic bullheads - have disappeared from the deep waters of the Oslof jord where they were known to exist in 1897 . We assume that unfavourable conditions, great changes in temperature or lack of oxygen in the stagnant deep water to which these species belonged have been injurious to their propagation and survival.

3. The annual fluctuations in the landed quantities of fish are great, but nevertheless there exists a marked decreasing trend since about 1930; total landings in recent years are less than $1 / 10$ of what they were 30 or 40 years ago.

4. The fluctuations in the landings of cod, herring and mackerel are studied in some detail. Three periods (of 20 to 22 years' duration) from 1872 to 1932 show increasing average landings of cod: 44,57, and 74 tons respectively; in the period 1933 to 1955 landings decreased to an average of 16 tons per year. The effect of fluctuating year classes is discussed.

5. The landings of herring and mackerel were very good between 1911 and 1919 or 1920 with a maximum of 1500 tons of herring and 800 tons of mackerel. In the following years there was a trend of decrease with a few years of moderately good landings. Mature mackerels are immigrating into the fjord for feeding and spawning, while mature herrings, to a major extent, are supposed to belong to a local 
stock. The highest landings of both species are due to extremely great catches of young fish, and the success of the fishery in any one year, therefore, dependent of a successful spawning and hatching one ort two years before.

6. In conclusion, the attention is drawn to the fact that there are reasons to believe that the profuse growth of bacteria in the polluted waters seems to be injurious to the hatching of fish eggs and to the survival of fish larvae (DanNevig 1945, OPPENHEIMER 1955).

\section{LITERATURE CITED}

Andersson, K. A., 1958. The stock of herring and herring-fisheries on the west coast of Sweden in the first half of the twentieh century. Rep. Inst. mar. Res. Lysekil (Ser. Biology) $8,1-41$.

DanNevig, A., 1945. Undersøkelser i Oslofjorden 1936-1940. FiskDir. Skr.(Ser. Havundersøk.) $8(4), 1-91$.

HJORT, J. \& DAHL, K., 1900. Fishing experiments in Norwegian fjords. Rep. Norw. Fishery mar. Invest. 1 (1), 1-215.

- \& Ruvd, J. T., 1938. Deep-sea prawn fisheries and their problems. Hvalråd.Skr. 17, 1-144.

LiD, G., 1967. Fiskeobservasjoner fra rekefeltene i Oslofjordens indre del. Fauna, Oslo 20 (2), 96-106.

Oppenhemer, C., 1955. The effect of marine bacteria on the development and hatching of pelagic fish eggs, and the control of such bacteria by antibiotics. Copeia 1, 43-49.

Ruud, J. T., 1939. Torsken i Oslofjorden. FiskDir. Skr. (Ser. Havundersøk.) 6 (2), 1-71.

Sund, O., 1936. The fluctuations in the European stocks of cod. Rapp. P.,v. Réun. Cons. perm. int. Explor. Mer 101, 1-18. 